\title{
Pemanfaatan Data Mining Dalam Memprediksi Produksi Pada PT Pupuk Sriwidjaja Palembang Menggunakan Algoritma Regresi Liniear Berganda
}

\author{
Adji Dwi Alfarizi \& Andri \\ Fakultas Teknik Ilmu Komputer, Universitas Bina Darma \\ Email: adjidwialfarizi23@gmail.com
}

\begin{abstract}
PT.Pupuk Sriwidjaja Palembang is a company that has the main task in the production and marketing of urea fertilizer and npk fertilizer. Production estimates are needed so that companies can determine strategies and breathrought so that the production process runs optimally. This study discusses the application of data mining in predicting the production of NPK Fertilizer Formula 15-15-15 PSO at PT.Pupuk Sriwidjaja Palembang. In its application, this research uses the multiple Linear Regression Algorithm by utilizing production history data for the 2019-2020 period. If you have already mined the production history data for the 2019-2020 period, there will bi predictions in 2021 which are predicted by the rapidminer application and using a multiple linear regression algorithm, which produces a predicted value of fertilizer production in 2021 as much as 70800 tons.
\end{abstract}

Keywords: Data Mining, production estimates, linear regression algorithm

\section{Pendahuluan}

Pupuk Sriwidjaja (Pusri) dalam penggunaan pupuk tidak bisa lepas dari proses produksi tanaman dalam membantu penyediaan unsur hara yang dibutuhkan tanaman baik itu bersifat organik maupun anorganik. PT. Pupuk Sriwidjaja (pusri) yang mengawali berdirinya industrialisasi pupuk di indonesia, didirikan di Palembang, Sumatera Selatan pada tahun 1959. Hingga kini Pusri memiliki 4 pabrik pupuk urea yaitu pabrik P-III,PIV,P-IB dan P-IIB serta 3 pabrik pupuk NPK. Pusri memulai operasional usaha dengan tujuan utama melaksanakan dan menunjang kebijaksanaan dan program pemerintah di bidang ekonomi dan pembangunan nasional, khususnya di industri pupuk dan kimia lainnya.

Informasi mengenai Prediksi Produksi Pupuk sangatlah di butuhkan agar perusahaan dapat menentukan strategi-strategi dan terobosan agar proses Produksi Pupuk berjalan maksimal. Berbagai perusahaan menyadari pentingnya sebuah prediksi masa depan untuk mengurangi ketidakpastian lingkungan. Perusahaan selalu menentukan sasaran dan tujuan, berusaha menduga faktor-faktor lingkungan, lalu memilih tindakan yang di harapkan akan menghasilkan pencapaian sasaran dan tujuan tersebut.

Dalam setiap tahunnya kebutuhan pupuk terus mengalami peningkatan. PT Pusri palembang memproduksi pupuk jenis NPK setiap hari dan dalam akumulasi 1 bulan saja formula yang diproduksi bisa bermacam-macam formula atau jenis pupuk NPK, maka dari itu dengan banyaknya pupuk NPK yang di produksi oleh PT Pusri Palembang, maka akan di ambil 1 jenis formula saja yang akan di teleti dan di prediksi yaitu pupuk NPK Formula 15-15-15 pupuk subsidi organik(PSO). pupuk ini tidak selalu di produksi setiap saat atau setiap hari tergantung dengan request konsumen atau pihak dari pemerintah langsung, karna pupuk ini bersifat subsidi. Tetapi dalam satu 
bulan pasti ada produksi pupuk tersebut begitu juga dengan bulan bulan selanjutnya atau bulan berjalan. Oleh karena itu data yang akurat sangatlah di perlukan. Namun seringkali ketersediaan informasi yang di perlukan tidak memadai di karenakan informasi harus di gali dari data yang jumlahnya besar, maka dari itu memprediksi pupuk NPK akan mendapatkan informasi yang berguna bagi PT Pusri.

Pupuk NPK adalah pupuk yang mengandung setidaknya 5 unsur hara yang terdiri dari 3 unsur hara makro ialah N, P dan K serta unsur hara mikro. Setiap jenis pupuk atau merek mempunyai persentase atau komposisi kandungan yang berbeda beda, yang di tandai dengan angka seperti yaitu NPK 16-16-16, NPK 15-15-15 atau NPK 12-12-12. Angka angka tersenut ialah persentase kandungan unsur hara makro yang ada di dalamnya. Sedangkan kandungan unsur hara mikro sangat sedikit sehingga umumnya tidak dapat di tulis pada kemasan. Adalah salah satu jenis pupuk majemuk dengan kandungan sangat lengkap. Baik itu makro maupun mikro, semuanya juga terdapat dalam pupuk tesebut. Penting sekali, dapat memberikan pupuk NPK terhadap tanaman karena ada unsur unsur pokok yang di butuhkan dalam rangka menyuburkan tanaman. Diantaranya seperti nitrogen, kalium, fosfot, klorida, boron, besi, mangan, kalsium, magnesium, sulfur, tembaga, seng serta masih banyak lagi.

Fungsi Prediksi merupakan bagian dari fungsi minor data mining. Prediksi adalah suatu cara untuk mencari kemungkinan hasil dari suatu hal pada masa akan datang. Pada teknologi data mining, metode peramalan digunakan sebagai alat bantu memprediksi kemungkinan akan datang berdasarkan bukti-bukti temuan pada data. Proses prediksi berhubungan erat dengan perhitungan matematik dan statistik, langkah prediksi dapat dilakukan menggunakan perhitungan rumus regresi linier matematika. Ada 2 jenis rumus regresi sebagai langkah proses analisis prediksi yaitu, regresi linear sederhana dan regresi linear berganda. Regresi Linier merupakan suatu cara mengukur data prediksi melalui garis lurus sebagai gambaran hubungan korelasi diantara 2 variabel atau lebih. Prediksi regresi linier, digunakan sebagai teknik mempelajari bagaimana hubungan variabel-variabel pada proses peramalan data. Cara membaca hubungan korelasi data hipotesis hasil analisis prediksi dilakukan melalui analisis statistik.

Data mining adalah suatu teknik menggali informasi berharga yang terpendam atau tersembunyi pada suatu koleksi data (database) yang sangat besar sehingga ditemukan suatu pola yang menarik yang sebelumnya tidak diketahui, Data mining merupakan serangkaian proses menemukan hubungan pola yang memiliki tujuan menyaring data yang sangat besar untuk mendapatkan bersifat benar, baru, bermanfaat, dan di dapatkan pemahaman terhadap suatu corak atau pola dari data tersebut.

Regresi linier berganda adalah analisis regresi yang menjelaskan hubungan antara variabel terikat (dependem) dengan faktor faktor yang mempengaruhi lebih dari satu variabel bebas (independen). Regresi linier sederhana dan regresi linier berganda hampir sama, hanya saja regresi berganda variabel bebasnya lebih dari satu variabel penduga. Tujuan analisis regresi linier berganda adalah untuk mengukur intensitas hubungan antara dua variabel atau lebih.

Informasi mengenai memprediksi produksi pupuk sangatlah penting dalam setiap pengambilan keputusan, pemanfaatan data yang ada di dalam sistem informasi untuk menunjang kegiatan pengambilan keputusan, tidak cukup hanya mengandalkan data operasional saja, di perlukan analisis data untuk menggali potensi-potensi informasi 
yang ada, penggunaan teknik data mining di harapkan dapat memberikan pengetahuanpengetahuan yang tersembunyi sehingga menjadi informasi yang berharga. Oleh karena itu data yang akurat sangatlah di perlukan bagi perusahaan, maka dari itu memprediksi pupuk NPK akan mendapatkan informasi yang menguntungkan bagi PT pusri.

Berdasarkan permasalahan di atas, di butuhkan sebuah teknik yang mampu mengolah data dalam jumlah besar, salah satunya dengan menggunakan teknik data mining, maka penulis tertarik untuk meneliti "Pemanfaatan Data Mining Dalam Memprediksi Produksi Pada PT. Pupuk Sriwidjaja Palembang Menggunakan Algoritma Regresi Linier Berganda “.

\section{Tinjauan Review}

Secara sederhana data mining adalah penambangan atau penemuan informasi baru dengan mencari pola atau aturan tertentu dari sejumlah data yang sangat besar (Davies, 2004). Data mining juga disebut sebagai serangkaian proses untuk menggali nilai tambah berupa pengetahuan yang selama ini tidak diketahui secara manual dari suatu kempulan data (Pramudiono, 2007). Data mining, sering juga disebut sebagai knowledge discovery in database (KDD). KDD adalah kegiatan yang meliputi pengumpulan, pemakaian data, historis untuk menemukan keteraturan, pola atau hubungan dalam set data berukuran besar (Santoso, 2007).

Data Mining adalah kegiatan menemukan pola yang menarik dari data dalam jumlah besar, data dapat disimpan dalam databases, data warehouse, atau penyimpanan informasi lainnya. Data mining berkaitan dengan bidang ilmu-ilmu lain, seperti database system, data warehousing, statistik, machine learning, information retrieval, dan komputasi tingkat tinggi. Selain itu, data mining di dukung oleh ilmu lain seperti neutral network, pengenalan pola, spatial data data analysism image database, signal processing (Han, 2006). Data mining didefinisikan sebagai proses menemukan pola-pola dalam data. Proses ini otomatis atau seringnya semiotomatis. Pola yang ditemukan harus penuh arti dan pola tersebut memberikan keuntungan, biasanya keuntungan secara ekonomi. Data yang dibutuhkan dalam jumlah besar (Witten, 2005).

Berdasarkan beberapa pengertian tersebut dapat di tarik kesimpulan bahwa data mining adalah suatu teknik menggali informasi berharga yang terpendam atau tersembunyi pada suatu koleksi data (database) yang sangat besar sehingga ditemukan suatu pola yang menarik yang sebelumnya tidak diketahui. Data mining merupakan serangkaian proses menemukan hubungan pola yang memiliki tujuan menyaring data yang sangat besar untuk mendapatkan bersifat benar, baru, bermanfaat, dan di dapatkan pemahaman terhadap suatu corak atau pola dari data tersebut (Han \& Kamber, 2006).

Secara umum operasi pada data mining dapat dibagi menjadi dua kelompok atau kategori yaitu metode deskriptif dan metode prediktif. Metode prediktif mempunyai tujuan untuk memperkirakan nilai dari suatu variabel berdasarkan nilai variabel-variabel lain, dimana hasilnya dapat digunakan untuk validasi hipotesis, pelaporan dan querying, sedangkan untuk metode deksriptif memiliki tujuan untuk menemukan pola atau anomali serta relasi dari sebuah data yang mudah untuk dipahami oleh manusia, hasil dari metode tersebut dapat dipergunakan untuk analisis data, database, eksplorasi, segmentasi, deteksi deviasi dan analisis keterkatitan (Adinugroho \& Sari, 2018). 
Menurut AMALIA (2018), Data mining memiliki beberapa metode antara lain :

1. Association rules (aturan asosiasi)

Teknik association rule merupakan suatu proses untuk menemukan semua aturan assosiatif yang memenuhi aturan atau syarat minimum untuk confidence (minimum confidence) dan syarat minimum untuk support (minimum support). Analisa asosiasi dikenal juga sebagai salah satu metode atau teknik data mining yang menjadi dasar dari berbagai macam metode data mining lainnya. Khususnya salah satu tahap dari analisis asosiasi yang disebut analisis pola frekuensi tinggi (frequent pattern mining), suatu aturan assosiatif dapat diketahui dengan dua parameter yakni support (nilai penunjang) yaitu prosentase kombinasi item tersebut dalam database dan confidence (nilai kepastian), eratnya ikatan antar item dalam aturan assosiatif. Dari sejumlah besar aturan yang mungkin dikembangkan, perlu mempunyai suatu aturan yang kuat tingkat ketergantungan antar item dalam consequent dan antecedent. Untuk mengukur kekuatan aturan asosiasi ini, digunakan ukuran confidence dan support. Confidence merupakan rasio antara jumlah transaksi yang meliputi semua item dalam consequent dan antecedent dengan jumlah transaksi yang meliputi semua item dalam antecedent sedangkan Support adalah rasio atau tingkatan antara jumlah transaksi yang memuat antecedent dan consequent dengan jumlah transaksi..

\section{Klasterisasi}

Merupakan suatu teknik dalam data mining yang membagi secara berkelompok dataset menjadi beberapa sub-net sedemikian rupa sehingga elemen-elemen dari kelompok tertentu memiliki set property yang di bagikan bersama dengan tingkat similaritas yang tinggi dalam suatu kelompok yang rendah. Sering disebut juga dengan "unsupervised learning".

3. Klasifikasi

Teknik klasifikasi merupakan metode dalam data mining yang berfungsi menentukan sebuah record data baru ke dalam salah satu dari beberapa kategori (kelas) yang sebelumnya telah didefinisikan, secara umum lebih dikenal dengan "sepervised learning".

4. Regresi

Merupakan metode pada data mining yang mempunyai tujuan untuk melakukan prediksi nilai dari suatu variabel lanjutan yang diberikan berdasarkan nilai dari variabel lainnya, dengan mengansumsikan sebuah model ketergantungan linier atau nonlinier.

\subsection{Data Warehouse}

Menurut Vidette Poe, data warehouse merupakan database yang bersifat analisis dan read only yang digunakan sebagai fondasi dari sistem penunjang keputusan.

Menurut W.H. Inmon dan Richard D.H., data warehouse adalah koleksi data yang mempunyai sifat berorientasi subjek,terintegrasi,time-variant, dan bersifat tetap dari koleksi data dalam mendukung proses pengambilan keputusan management.

\subsection{Data Mining}


Data Mining adalah kegiatan menemukan pola yang menarik dari data dalam jumlah besar, data dapat disimpan dalam databases, data warehouse, atau penyimpanan informasi lainnya. Data mining berkaitan dengan bidang ilmu-ilmu lain, seperti database system, data warehousing, statistik, machine learning, information retrieval, dan komputasi tingkat tinggi.

Data mining memiliki komponen-komponen utama dalam data mining antara lain :

1. Database dan data warehouse, World Wide Web, atau tempat penyimpanan informasi lainnya, dapat berbentuk satu ataupun banyak database, spreadsheet, data warehouse maupun tempat penyimpanan informasi lainnya. Data cleaning, data selection dan data integration dapat dijalankan pada data tersebut.

2. Database dan data warehouse server, pada bagian ini memliki tanggung jawab untuk hal pengambilan data yang memiliki sifat relevan, didasarkan permintaan pengguna.

3. Knowledge Based, bagian ini merupakan domain knowledge yang dipergunakan untuk memberi arahan terhadap pencarian atau melakukan evaluasi pola-pola yang didapatkan. informasi tersebut meliput hirarki konsep yang dipergunakan untuk mengorganisasikan atribut atau nilai atribut kedalam level abstraksi yang berbeda. informasi tersebut juga dapat berupa kepercayaan pengguna (user belief), yang dapat dipergunakan dalam menentukan pola menarik yang didapatkan.

4. Data mining engine, merupakan suatu bagian yang penting dalam arsitektur sistem data mining. Bagian ini terdiri atas modul-modul fungsional seperti asosiasi, analisis cluster, karakterisasi dan klasifikasi.

5. Ghrapical user interface (GUI). Modul ini berinteraksi dengan pengguna (user) dan data mining melalui komponen ini, pengguna dapat berkomunikasi dengan sistem menggunakan query.

\subsection{Regresi Linier Berganda}

Regresi linier berganda adalah perkembangan dari regresi sederhana yang menjelaskan hubungan antara variabel terikat dengan lebih dari satu variabel bebas (Freund, Wilson, \& Sa, 2006 : 73). Tujuan utama analisis regresi linier berganda sama seperti dengan regresi sederhana, yaitu menggunakan hubungan antara variabel terikat (response) dan variabel bebas (factor) untuk memprediksi atau menjelaskan karakteristik dari variabel (Freund, Wilson, \& Sa, 2006 : 73). Secara umum model regresi linier berganda dapat dituliskan sebagai berikut:

$$
Y=\beta o+\beta 1 \mathrm{X} 1+\beta 2 \mathrm{X} 2+\beta 3 \mathrm{X} 3+\ldots \beta \mathrm{nXn}
$$

Keterangan:

$\mathrm{Y}$

: Nilai penduga bagi variabel $Y$

Bo $\quad$ : dugaan bagi parameter kontanta

$\mathrm{b} 1, \mathrm{~b} 2, \ldots \mathrm{bk} \quad$ : dugaan bagi paramener konstanta $\beta 1, \beta 2, \ldots \beta \mathrm{n}$

X : Variabel bebas

\section{Metode Penelitian}


Metode pengumpulan data yang digunakan dalam penelitian ini adalah :

a. Pengamatan langsung (Observasi)

Yaitu metode pengumpulan data dengan cara mengadakan tinjauan secara langsung ke objek yang di teliti. Untuk mendapatkan data yang bersifat nyata dan menyakinkan maka penulis melakukan pengamatan langsung ke PT Pupuk Sriwidjaja Palembang bagian Rendal Produksi.

b. Wawancara

Merupakan suatu pengumpulan data yang dilakukan dengan cara tanya jawab atau dialog secara langsung dengan pihak-pihak yang terkait dengan penelitan yang dilakukan. Dalam hal ini penulis melakukan tanya jawab kepada pihak panitia atau yang mengelola data tersebut yang ada di bagian rendal produksi.

c. Studi Pustaka (Literature)

Merupakan metode pengumpulan data dari sumber yang dapat di jadikan rujukan seperti buku-buku ataupun referensi lain yang berhubungan dengan penelitian.

Sumber data yang digunakan pada penelitian ini adalah produksi pupuk formula npk 1515-15 PSO pada PT Pusri Sriwidjaja Palembang pada tahun 2019-2020.

\subsection{Data Selection}

Pemilihan data dilakukan sebelum tahap pengumpulan data di $K D D$ dimulai. Data dari hasil seleksi yang digunakan untuk proses data mining disimpan dalam berkas yang terpisah dari database yang dapat dieksekusi. Sebelum masuk ke dalam tahap data preprocessing, yang harus dilakukan adalah pemilihan data (data selection).

Berikut ini adalah data yang belum diseleksi yang terdiri dari bulan, tahun, satuan(ton) dan downtime dari Januari 2019 sampai dengan Desember 2020.

\begin{tabular}{|l|l|l|l|l|l|l|}
\hline \multirow{2}{*}{ Bulan } & \multicolumn{3}{|c|}{ Tahun 2019 } & \multicolumn{3}{c|}{ Tahun 2020 } \\
\cline { 2 - 7 } & $\begin{array}{l}\text { Down } \\
\text { Time } \\
\text { (Ton) }\end{array}$ & $\begin{array}{l}\text { Produksi } \\
\text { Produksi } \\
\text { (Ton) }\end{array}$ & $\begin{array}{l}\text { Down } \\
\text { Time } \\
\text { (Ton) }\end{array}$ & $\begin{array}{l}\text { Produksi } \\
\text { Produksi } \\
\text { (Ton) }\end{array}$ \\
\hline Januari & 28 & 285 & 300 & 10 & 9468 & 10000 \\
\hline Februari & 4 & 7905 & 8000 & 11 & 7585 & 7800 \\
\hline Maret & 13 & 7687 & 7800 & 12 & 7123 & 7500 \\
\hline April & 2 & 9187 & 9300 & 12 & 7182 & 7500 \\
\hline Mei & 10 & 4644 & 5000 & 9 & 3832 & 4000 \\
\hline Juni & 1 & 8544 & 8700 & 10 & 8418 & 9000 \\
\hline Juli & 7 & 8562 & 9000 & 14 & 3111 & 3500 \\
\hline Agustus & 5 & 9352 & 9500 & 11 & 3513 & 4000 \\
\hline September & 7 & 7926 & 8000 & 14 & 5502 & 6000 \\
\hline Oktober & 7 & 3622 & 4000 & 12 & 2860 & 3000 \\
\hline Nopember & 2 & 2835 & 3000 & 15 & 3787 & 4000 \\
\hline Desember & 3 & 10053 & 10100 & 15 & 4350 & 4500 \\
\hline Total & 89 & 80593 & 85300 & 145 & 66730 & 70800 \\
\hline
\end{tabular}

Gambar 1. Data Selection

\subsection{Proproccessing}

Tahapan ini akan melakukan kegiatan pembersihan data (data cleaning) dan menggabungkan data yang sudah ada (integrasi data).

\subsubsection{Data Cleaning}

Pembersihan data (data cleaning) merupakan bagian dari tahapan dalam data mining, tahapan data cleaning dilakukan untuk menghapus data yang sama, mengecek data yang 
tidak konsisten serta melakukan perbaikan data, Selain itu juga syarat yang harus dilakukan dalam preprocessing adalah tidak terdapat missing value sehingga menghasilkan sebuah dataset yang sesuai untuk dapat digunakan pada proses selanjutnya. Berikut ini adalah sampel data produksi pupuk pada tahun 2019 sampai tahun 2020 :

\begin{tabular}{l|l|l|l|l|l|l|}
\multirow{2}{*}{} & \multicolumn{2}{|l|}{ Tanun 2019 } & \multicolumn{2}{|l|}{ Ianun 2020 } \\
\cline { 2 - 7 } & $\begin{array}{l}\text { Down } \\
\text { Time }\end{array}$ & Produksi & $\begin{array}{l}\text { Total } \\
\text { Produksi }\end{array}$ & $\begin{array}{l}\text { Down } \\
\text { Time }\end{array}$ & Produksi & $\begin{array}{l}\text { Total } \\
\text { Produksi }\end{array}$ \\
\hline Januari & 28 & 285 & 300 & 10 & 9468 & 10000 \\
\hline Februari & 4 & 7905 & 8000 & 11 & 7585 & 7800 \\
\hline Maret & 13 & 7687 & 7800 & 12 & 7123 & 7500 \\
\hline April & 2 & 9187 & 9300 & 12 & 7182 & 7500 \\
\hline Mei & 10 & 4644 & 5000 & 9 & 3832 & 4000 \\
\hline Juni & 1 & 8544 & 8700 & 10 & 8418 & 9000 \\
\hline Juli & 7 & 8562 & 9000 & 14 & 3111 & 3500 \\
\hline Agustus & 5 & 9352 & 9500 & 11 & 3513 & 4000 \\
\hline September & 7 & 7926 & 8000 & 14 & 5502 & 6000 \\
\hline Oktober & 7 & 3622 & 4000 & 12 & 2860 & 3000 \\
\hline Nopember & 2 & 2835 & 3000 & 15 & 3787 & 4000 \\
\hline Desember & 3 & 10053 & 10100 & 15 & 4350 & 4500 \\
\hline
\end{tabular}

Gambar 2. Data Cleaning

\subsubsection{Data Integration}

Merupakan tahap menggabungkan data dari sumber yang berbeda. Adapun data yang dipakai pada penelitian ini merupakan data produksi pupuk pada tahun 2019 sampai tahun 2020, lalu digabungkan menjadi satu untuk keperluan kegiatan data mining.

Pada proses integrasi ini tidak di perlukan lagi dikarenakan data produksi pupuk tahun 2019 hingga 2020 sudah tergabung menjadi satu file. Berikut ini adalah tampilan sampel data nya :

\begin{tabular}{l|l|l|l|l|l|l|}
\multirow{2}{*}{} & \multicolumn{2}{|l|}{ Banun 2019} & \multicolumn{2}{l|}{ Ianun 2020 } \\
\cline { 2 - 7 } & $\begin{array}{l}\text { Down } \\
\text { Time }\end{array}$ & Produksi & $\begin{array}{l}\text { Total } \\
\text { Produksi }\end{array}$ & $\begin{array}{l}\text { Down } \\
\text { Time }\end{array}$ & $\begin{array}{l}\text { Produksi } \\
\text { Produksi }\end{array}$ \\
\hline Januari & 28 & 285 & 300 & 10 & 9468 & 10000 \\
\hline Februari & 4 & 7905 & 8000 & 11 & 7585 & 7800 \\
\hline Maret & 13 & 7687 & 7800 & 12 & 7123 & 7500 \\
\hline April & 2 & 9187 & 9300 & 12 & 7182 & 7500 \\
\hline Mei & 10 & 4644 & 5000 & 9 & 3832 & 4000 \\
\hline Juni & 1 & 8544 & 8700 & 10 & 8418 & 9000 \\
\hline Juli & 7 & 8562 & 9000 & 14 & 3111 & 3500 \\
\hline Agustus & 5 & 9352 & 9500 & 11 & 3513 & 4000 \\
\hline September & 7 & 7926 & 8000 & 14 & 5502 & 6000 \\
\hline Oktober & 7 & 3622 & 4000 & 12 & 2860 & 3000 \\
\hline Nopember & 2 & 2835 & 3000 & 15 & 3787 & 4000 \\
\hline Desember & 3 & 10053 & 10100 & 15 & 4350 & 4500 \\
\hline
\end{tabular}

Gambar 3. Data Integration

\subsection{Simulasi Data Menggunakan Regresi Linier Berganda}

Pada proses simulasi data menggunakan data pada tahun 2019 hingga tahun 2020, dengan memprediksi untuk 1 tahun kedepan dengan cara menghitung perbulannya, berikut ini merupakan tabel data simulasi yang dihitung menggunakan algoritma regresi linier berganda.

Simulasi prediksi yang dilakukan adalah memprediksi jumlah produksi pupuk npk untuk 1 tahun kedepan. Berikut ini merupakan penghitungan prediksi penjumlahan produksi 
pupuk dengan cara manual untuk memprediksi jumlah produksi pupuk pada bulan januari sampai dengan desember 2021 menggunakan regresi linier berganda :

Rumus:

$$
\begin{aligned}
& b_{1}=\frac{\left(\Sigma x \frac{2}{2}\right)\left(\Sigma x_{1} y\right)-\left(\Sigma x_{2} y\right)\left(\Sigma x_{1} x_{2}\right)}{\left(\Sigma x \frac{1}{2}\right)\left(\Sigma x \frac{2}{2}\right)-\left(\Sigma x_{1} x_{2}\right)^{2}} \\
& \mathrm{~b}_{2}=\frac{\left(\Sigma x_{\frac{2}{1}}^{2}\right)\left(\Sigma x_{2} y\right)-\left(\Sigma x_{1} y\right)\left(\Sigma x_{1} x_{2}\right)}{\left(\Sigma x_{\frac{2}{1}}^{2}\right)\left(\Sigma x_{\frac{2}{2}}^{2}\right)-\left(\Sigma x_{1} x_{2}\right)^{2}} \\
& \mathrm{a}=\frac{\left.\Sigma Y-b_{1} \Sigma X_{1}-b_{2} \Sigma x_{2}\right)}{n}
\end{aligned}
$$

Di mana:

$$
\begin{gathered}
\Sigma x \frac{2}{1}=\Sigma X \frac{2}{1}-\frac{\left(\Sigma X_{1}\right)^{2}}{n} \\
\Sigma x \frac{2}{2}=\Sigma X \frac{2}{2}-\frac{\left(\Sigma X_{2}\right)^{2}}{n} \\
\Sigma x_{1} x_{2}=\Sigma X_{1} X_{2}-\frac{\left(\Sigma X_{1}\right)\left(\Sigma X_{2}\right)}{n} \\
\Sigma x_{1} y=\Sigma X_{1} Y-\frac{\left(\Sigma X_{1}\right)(\Sigma Y)}{n} \\
\Sigma x_{2} y=\Sigma X_{2} Y-\frac{\left(\Sigma X_{2}\right)(\Sigma Y)}{n} \\
\Sigma y^{2}=\Sigma Y^{2}-\frac{(\Sigma Y)^{2}}{n}
\end{gathered}
$$

Dimana nilai $a, b_{1}, b_{2}$ dapat dihitung menggunakan persamaan normal.

$\Sigma Y=\mathrm{a}+\mathrm{b}_{1} \mathrm{X}_{1}+\mathrm{b}_{2} \mathrm{X}_{2}$

$\Sigma X_{1} \mathrm{Y}=\mathrm{a} \Sigma X_{1}+\mathrm{b}_{1} \Sigma X_{1}^{2}+\mathrm{b}_{2} \Sigma X_{1} \mathrm{X}_{2}$

$\Sigma X_{2} \mathrm{Y}=\mathrm{a} \Sigma X_{2}+\mathrm{b}_{1} \Sigma X_{1} \mathrm{X}_{2}+\mathrm{b}_{2} \Sigma \mathrm{X}_{2}$

$\mathrm{Y}=\mathrm{a}+\mathrm{b}_{1} \mathrm{X}_{1}+\mathrm{b}_{2} \mathrm{X}_{2}+\ldots+\mathrm{b}_{\mathrm{n}} \mathrm{X}_{\mathrm{n}}$

\subsection{Pattern Evaluation}

Pattern Evaluation adalah kegiatan mengenali model yang menarik pada knowledge based yang didapatkan. Pada tahap ini nantinya akan menghasilkan model-model yang khusus, berupa model prediksi dan di evaluasi untuk mengukur informasi yang ditemukan apakah telah sesuai atau belum dengan hipotesa yang sudah ada sebelumnya. 
Dalam melaksanakan prediksi atas estimasi produksi pupuk pada tahun 2021, dengan memasukan nilai Y di bulan Januari - Desember tahun 2019 sampai tahun 2020 ke dalam persamaan regresi linier berganda yang telah didapat.

\section{Hasil dan Pembahasan}

\subsection{Implementasi Rapidminer}

Aplikasi rapidminer dapat menghasilkan informasi yang tidak banyak diketahui oleh pengguna, sehingga hasil yang didapatkan nantinya dapat digunakan untuk dijadikan acuan pada kegiatan pengambilan keputusan. Algoritma regresi linier berganda digunakan peneliti untuk memprediksi jumlah produksi pupuk pada penelitian ini.

\subsubsection{Prediksi Produksi Pupuk Per-Bulan}

Tahap selanjutnya data diolah kembali menggunakan aplikasi rapidminer dengan bagian operator yang di gunakan pada proses prediksi dengan menggunakan regresi linier berganda adalah read excel dan validation. Berikut ini merupakan proses dalam memprediksi produksi pupuk menggunakan aplikasi rapidminer:

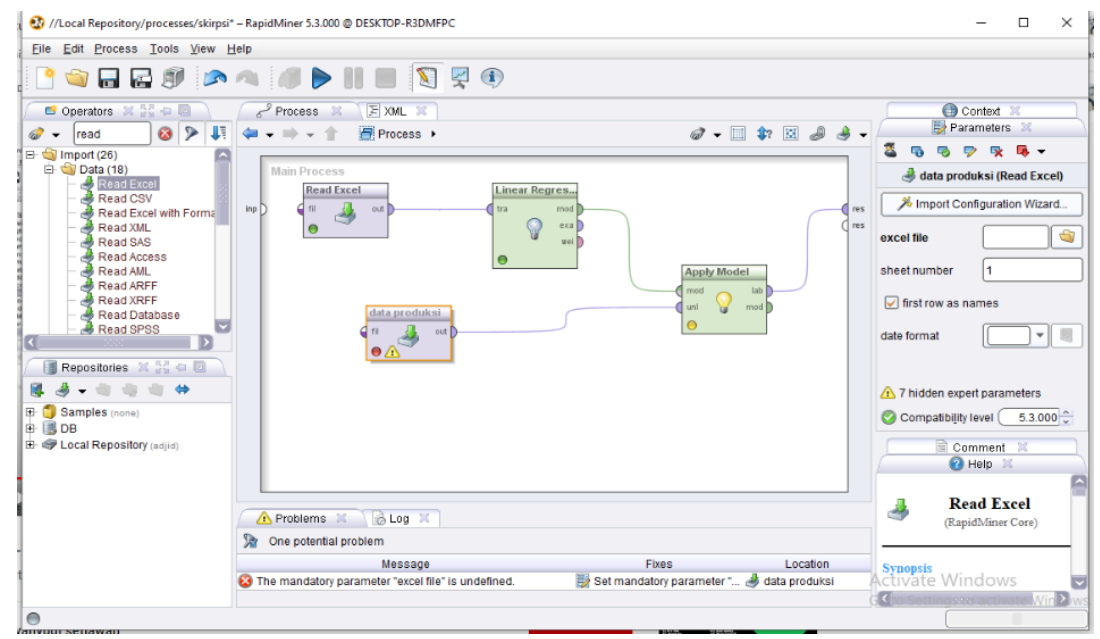

Gambar 4. Proses Prediksi Menggunakan Aplikasi Rapidminer

\subsubsection{Prediksi Per-Pupuk}

Pada proses prediksi produksi pupuk per-bulan menggunakan aplikasi rapidminer maka proses yang dilakukan sama halnya dengan proses prediksi jumlah penjualan barang pertahun tetapi terdapat perbedaan data yang akan diinputkan ke dalam data uji (data testing) dan data training, yakni data yang diinputkan kedalam data training dan data uji adalah data per-bulan.

Berikut ini adalah tampilan dari data training dan data uji yang digunakan untuk memprediksi jumlah penjualan per-bulan pada tahun 2021 menggunakan aplikasi rapidminer: 


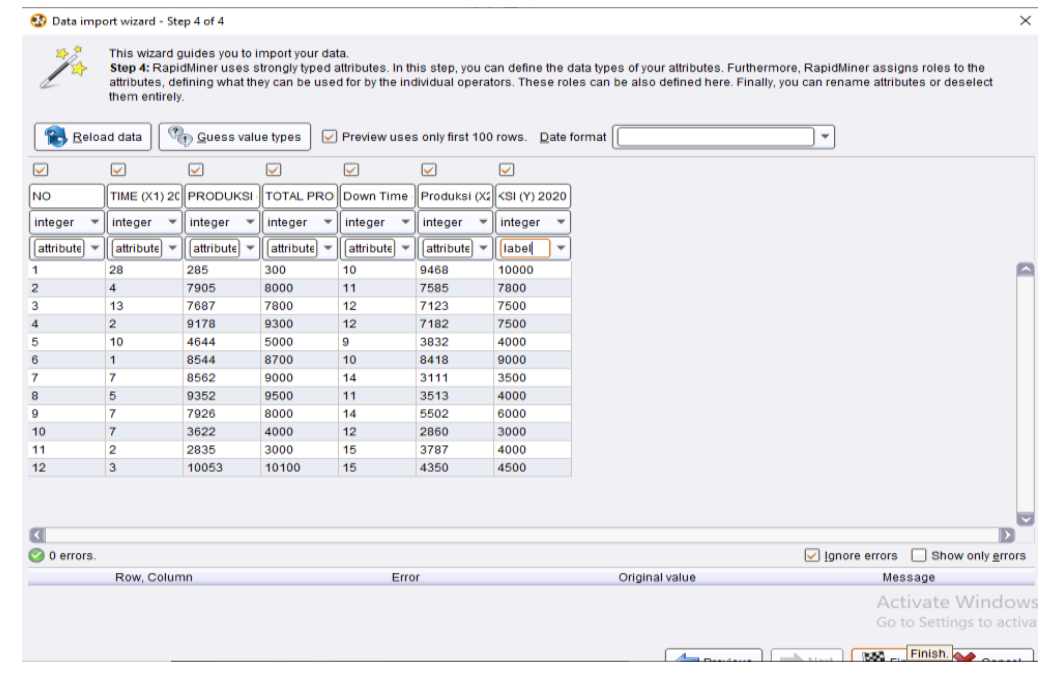

Gambar 5. Data Uji Per-Bulan

Terdapat 7 variabel data yang di input pada data uji (testing) per-bulan yakni, variable No, Down Time (X1), Produksi (X2), Total Produksi (Y), Down Time (X1), Produksi (X2), Total Produksi (Y), data yang di input merupakan data produksi dari tahun 2019 hingga tahun 2020.

Setelah dilakukan tahapan-tahapan proses dalam memprediksi produksi pupuk per-bulan menggunakan aplikasi rapidminer makan akan didapatkan hasil dari prediksi produksi per-bulan tersebut. Berikut ini adalah hasil dari prediksi tersebut:

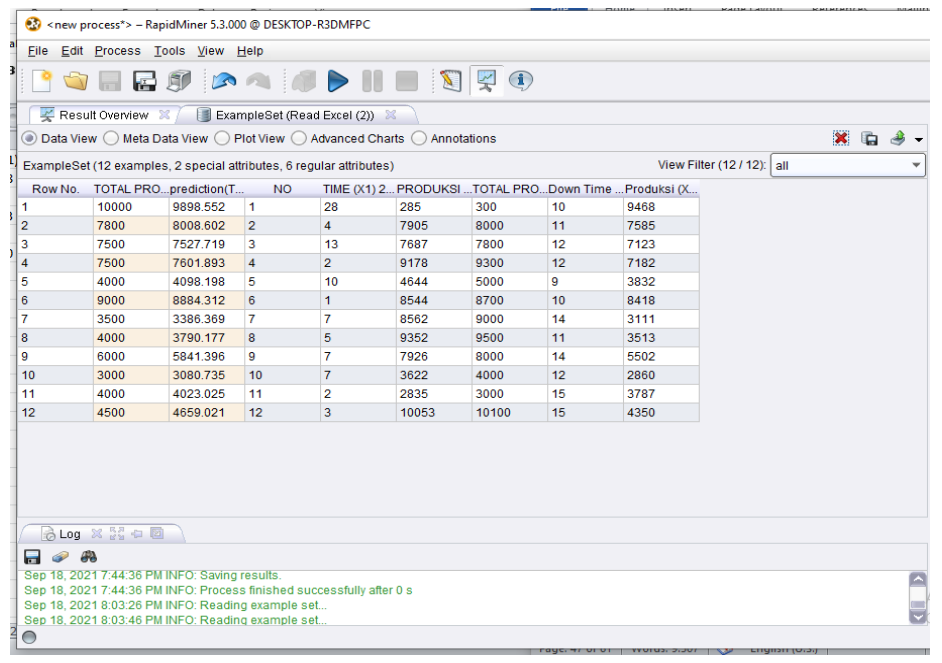

Gambar 6. Hasil Prediksi Produksi Pupuk Per-Bulan

Hasil yang didapatkan pada proses prediksi produksi per-bulan yang ditampilkan pada gambar 6, terdapat 9 kolom atau variabel yang ditampilkan antara lain kolom nomor row yang berisikan urutan nomor data, kolom no yang berisikan urutan nomor data perbulan, kolom down time yang berisikan data down time per-bulan yang di prediksi, kolom produksi yang berisikan data produksi per-bulan yang di prediksi, kolom total produksi yang berisikan data total produksi per-bulan yang akan di prediksi, sedangkan kolom prediction merupakan kolom yang berisikan hasil prediksi Total Produksi (Y) untuk tahun 2021. 


\subsubsection{Mengukur Tingkat Kesalahn (Error)}

Pada tahapan ini di lakukan pengukuran tingkat error atau mean absolut percantage error (MAPE), tujuan dari mengukur MAPE adalah untuk melihat jarak nilai prediksi dengan faktanya. Berikut ini adalah proses prediksi untuk pengukuran tingkat kesalahan:

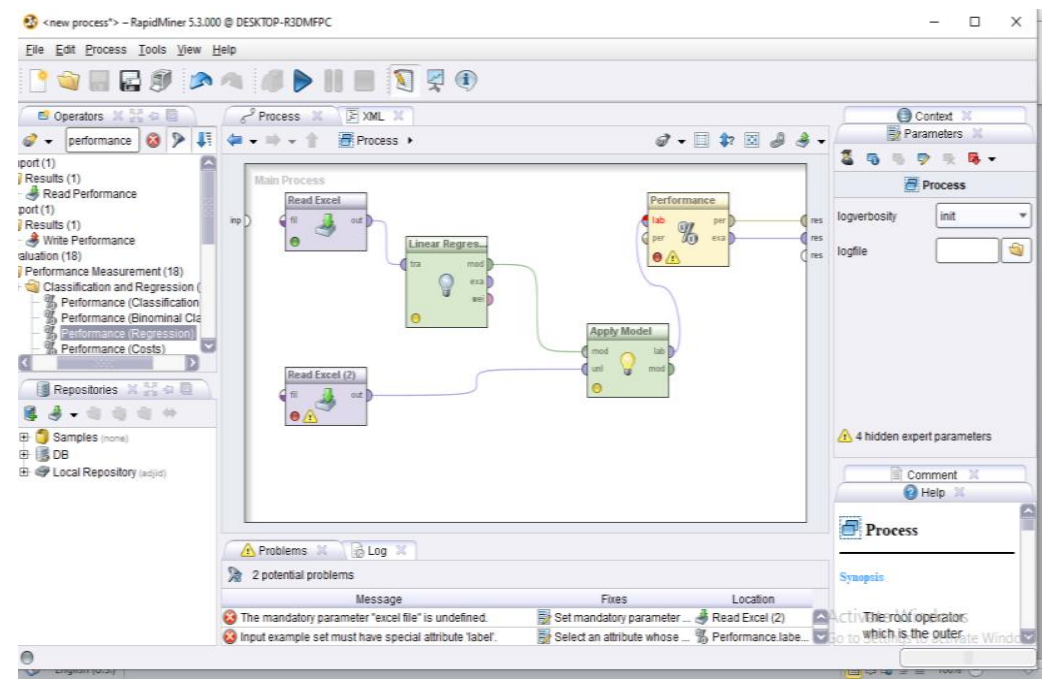

Gambar 7. Proses Prediksi Untuk Mengukur Tingkat Kesalahan

Pada proses prediksi untuk mengukur tingkat kesalahan atau mean absolut percantage error, terdapat perbedaan dengan proses prediksi penjualan sebelumnya, karena ada penambahan operator performance (regression), dimana mana tujuan dari operator tersebut adalah untuk mengukur tingkat mean absolut percantage error dari data produksi pupuk yang telah di prediksi tadi. Berikut ini adalah tampilan dari data produksi pupuk yang di input dan di proses:

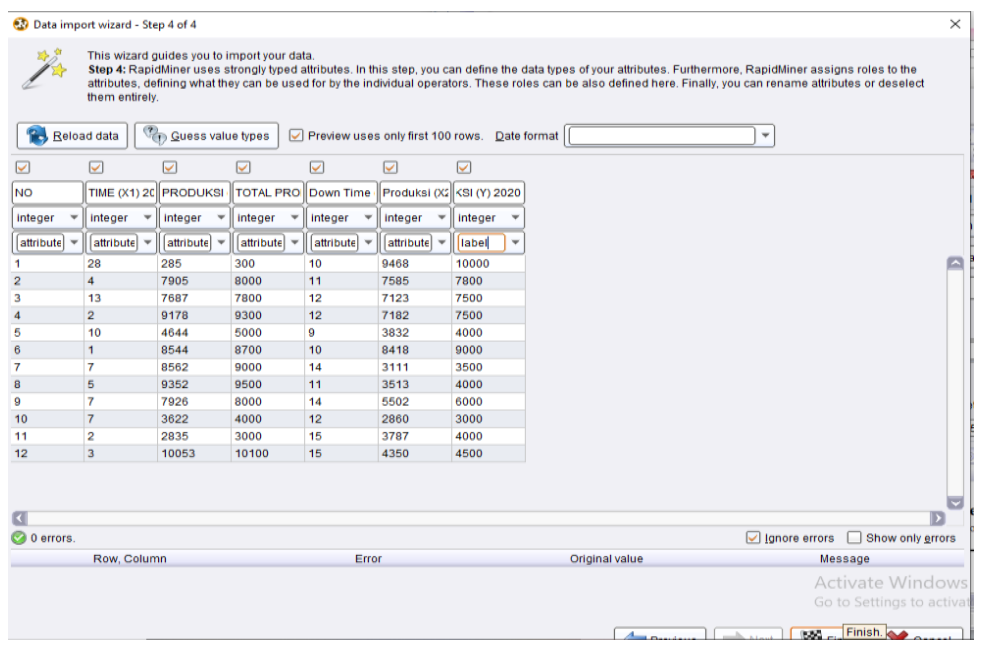

Gambar 8. Data Prediksi Untuk Mengukur Tingkat Kesalahan (Testing)

Terdapat 7 variabel data yang di input ke data testing pada proses prediksi untuk mengukur tingkat kesalahan yaitu, , variable NO, Time (X1), Produksi (X2), Total Produksi (Y), Down Time (X1), Produksi (X2), Total Produksi (Y), di tahapan ini data yang pakai merupakan keseluruhan data produksi pupuk di tahun 2020.

Berikut ini adalah hasil yang didapatkan dari proses prediksi untuk mengukur tingkat 
kesalahan:

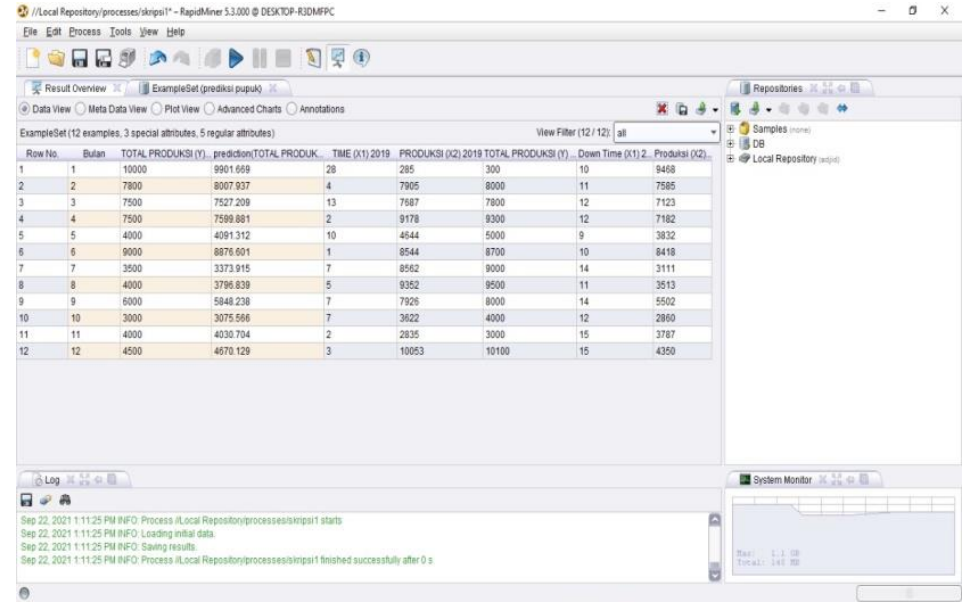

Gambar 9. Hasil Prediksi Untuk Mengukur Tingkat Kesalahan

Berdasarkan gambar di atas hasil yang didapatkan dari proses prediksi untuk mengukur tingkat kesalahan prediksi jumlah produksi pupuk.

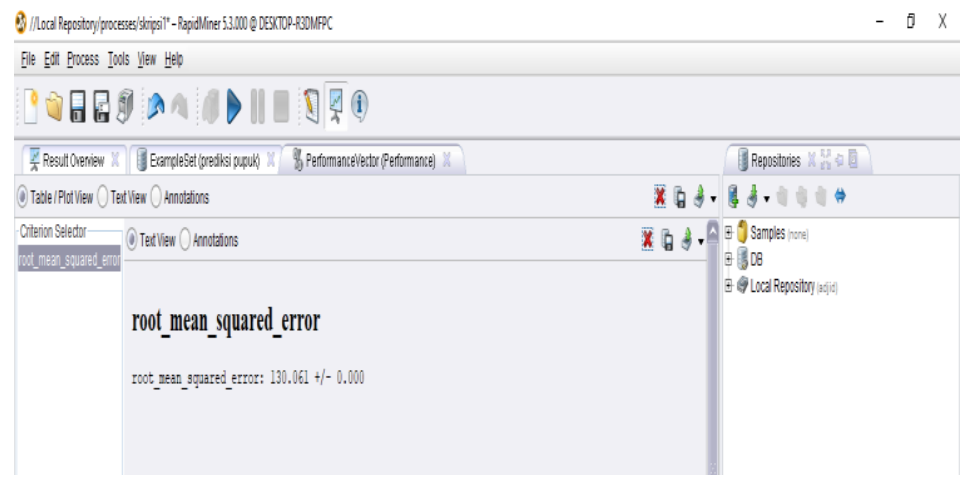

Gambar 10. Nilai Root Mean Squared Error (RMSE)

Nilai Root Mean Squared error yang didapatkan dari prediksi untuk mengukur tingkat kesalahan adalah 130.061. Nilai yang lebih rendah menunjukan nilai lebih baik. Jika nilai RMSE lebih kecil, maka nilai yang diprediksi dekat dengan nilai yang di amati atau observasi, dan sebaliknya

\subsubsection{Pembahasan Hasil}

Hasil yang didapatkan dari proses prediksi untuk mengukur tingkat kesalahan terdapat beberapa hasil yang ditampilkan antara lain:

1. Hasil yang didapatkan pada prediksi untuk mengukur tingkat kesalahan menggunakan data testing tahun 2020 dengan nilai variabel data testing, downtime (X1) sebesar 145, produksi (X2) sebesar 66730 dan total produksi (Y) sebesar 70800, menghasilkan nilai prediksi total produksi pupuk sebanyak 70800 .

2. Nilai Root Mean Squared Error (RMSE) yang didapatkan adalah sebesar 130.061 .

\section{Kesimpulan}

Dari hasil yang telah di dapatkan berdasarkan penghitungan prediksi algoritma regresi linier berganda, maka hasil prediksi produksi pupuk yang di dapatkan antara lain: 
1. Menghasilkan prediksi produksi pupuk pada tahun 2021 sebanyak 70800 produksi pupuk.

2. Pengujian aplikasi rapid miner menggunakan data testing tahun 2020 dengan nilai variabel data testing, downtime (X1) sebesar 145, produksi (X2) sebesar 66730 dan total produksi (Y) sebesar 70800, menghasilkan nilai prediksi total produksi pupuk sebanyak 70800 produksi pupuk dan menghasilkan Nilai root mean squared error sebesar 130.061.

\section{Referensi}

Suyanto, 2018. Data Mining Untuk Klasifikasi dan Klasterisasi Data. Bandung:Informatika.

Anonim (2018). Sejarah PT. Pupuk Sriwidjaja Palembang. Diambil dari : www.pusri.co.id/ina/profil-sekilas-perusahaan/), diakses pada 10Desember 2020.

Han, J.,\&Kamber, M. (2006). Data Mining Concept and Tehniques.San Fransisco: Morgan Kauffman.

Fraticasari, S. Y., 2018. Optimasi Pemodelan Regresi Linier Berganda Pada Prediksi Jumlah Kecelakaan Sepeda Motor Dengan Algoritme Genetika. Pengembangan Teknologi Informasi dan Ilmu Komputer, pp. 1932-1939.

Afkarina,Nur Kholida,Agus Wahyu Widodo,Muhammad Tanzil Furqon (2019). Implementasi Regresi Linier Berganda Untuk Prediksi Jumlah Peminat Mata Kuliah Pilihan.

Vulandari, Retno Tri. 2017. Data Mining Teori dan Aplikasi RapidMiner. Yogyakarta:Penerbit Gava Media.

Sumarti,Murti.,\&Soeprihanto1987.Pengantar Ekonomi.Yogyakarta:BPEE-UGM.

\section{Copyrights}

Copyright for this article is retained by the author(s), with first publication rights granted to the journal.

This is an open-access article distributed under the terms and conditions of the Creative Commons Attribution license (http://creativecommons.org/licenses/by/4.0/) 